\title{
JUVENILE DELINQUENCY IN MALTA
}

\author{
Paul Muscat \\ Assistant Director, Social Services, \\ Ministry of Labour, Employment and Welfare
}

I have been invited to talk on juvenile delinquency in Malta but you will agree with me that in a thirty-minute talk I cannot be expected to do justice to such a vast and complicated theme. I have therefore decided to limit myself to certain aspects of it, to highlight some of the problems facing those dealing with young persons who have gone astray and to put forward to you a few proposals aiming at having a better service for the reeducation and rehabilitation of wayward youths.

\section{Causation of crime}

The first and by far the biggest problem the world is facing in its treatment of delinquency emanates from the fact that we know so little about the causation of crime with any scientific precision. But the first question we have to answer is "Why do young persons commit offences?" If such a question were asked, say a hundred years ago, the reply to it would have been a simple, straight forward one. "Men commit crimes", we would have said, "because they are born criminals". This at least was the theory of the famous Italian criminologist, Lombroso, who in his book "L'uomo Delinquente", published in 1876 , went so far as to state that one could also determine whether a person was a criminal or not by certain physical characteristics. He mentioned among the se a small cránium, a receding forehead, projecting ears, a thin upper lip, little beard on the face and a luxuriant growth of hair on the head. There are, however, Saints with such facial features and I need hardly stres s that such a theory was attacked from the very beginning, was amended by Lombroso himself to include the influence of the environment, and ultimately the whole theory was completely exploded by Dr Charles Goring in 1913 in his book, "The English Convict".

Since then innumerable researches have been undertaken into the causation of crime in most countries by different people working together or separately, volumes have been written, explanations produced and still no final answer is in sight. We now know that the subject is far more complicated than was real realised a hundred years ago. 
Some modern researches still attempt to find a correlation between criminality and physique, though in a different form from that put forward by Lombroso. We find, for example, the works of E. Kretschmer (1) and the studies of W.A. Sheldon (2). Two leading American criminologists, Sheldon and

Eleonor Glueck (3) have shown that a certain stocky physical type is more common amongst delinquents than non-criminal youth. But this is recognised as only one factor amongst many and definitely not indicating a "born criminal". The world is indeed fortunate that no definite evidence has been given that crime is hereditary, because if it were so, then all our efforts would be wasted as there is nothing that can be done to change heredity.

In an attempt to examine deeply the reasons why some of our youth go astray, researches today are becoming more and more concerned with psychological causes and the importance of the home environment, with emphasis on early training and on economic social and moral influences.

The need for more research, however, and the pooling of our resources to find an answer to the question of what causes crime, is one of the proposals I wish to put forward in this seminar.

The young offender and mental illness

Young offenders are sometimes referred to us who on closer examination are found to be suffering from an abnormal state of mind, usually a mental illness that attacks people at an early age of their life. A young man referred for having committed theft, rape, arson or some sex offence may be found to be suffering from incipient schizophrenia. An offence involving assault may be found to have been committed by a paranoid patient, who in his deluded state, attacks those whom he believes are plotting against him. The epileptic may commit offences during a period of mental confusion after the fit has ended. Such offences as sexual exhibitionism, wandering and stealing may be performed repeatedly by the obsessional neurotic through some irresistible inner compulsion. Such abnormal mental states are not easily visible and it requires a highly qualified social worker to detect indications of such a mental state, enough to enable him to refer the client immediately for expert psychiatric examination, advice and treatment. Criminal acts often disappear as soon as the mental condition is arrested, even if not cured. I am happy to report that our social workers are trained and that there is very close co-operation between the Welfare Service and the 
psychiatric services in Malta. The need for more such qualified staff, however, still exists.

The young offender as a product of faulty early

training and adverse home environment

The influence of the moral standards of the home on the development of youth is self-evident. If there is no recognition of the difference between right and wrong, no values placed on self-control, on consideration for others or on the acceptance of responsibility, it is hard for the child to acquire the qualities necessary for good leadership.

It has also been amply proved that inconsistent discipline at home produces unreliable and irresponsible youth. One parent may be too harsh or arbitrary in his discipline, the other overprotective and over indulgent. Or the child may be alternately spoilt and clouted according to the mood of the parent. As Sir Cyril Burt in his "Young Delinquent" published 1948, points out, this double-track discipline is the most harmful of all.

Probation Officers, social workers in prisons, Approved Schools and Borstals have all come across the socalled "affectionless, persistent offender" and they seem generally agreed that such persons are difficult to reach, that they appear shallow in their attachments and almost completely unable to make any satisfactory relationships with others. They lie, they steal and simply do not care whether they are in favour or out of favour. Their case-histories more of ten than not indicate quite clearly that they suffered from maternal deprivation at an early age of their life, were admitted to and transferred from one Children's Home after another. Most of them appear to have suffered frequent disappointments by the resultant continuous change in their mother-figures. It is not therefore surprising to find that their life seems to have been built completely on an impersonal basis.

A study made by Dr John Bowlby (4) and presented to the World Health Organization proves beyond doubt that the "affectionless" offender is the product of maternal deprivation (i.e. deprivation of a mother-figure, who could give love and security) especially if this occurs in the first five years of life. What strikes us most in this study, however, is Dr. Bowlby's contention that this condition of affectionless young offender is practically incurable. 
However, if this condition cannot be cured, we know that it can be prevented and my main proposal here is that every attempt should be made to prevent such a condition from ever developing.

In Malta we have attempted to solve this problem by the setting up of the Welfare Division within the Ministry of Labour, Employment and Welfare, and provide coherent administrative machinery for multi-purpose social work with emphasis on family casework, the care of the deprived child and the treatment of delinquency. The Family Service is the pivot around which the whole scheme devolves and it aims at preventing the deterioration and breakdown of families instead of simply providing an ambulance service to convey children to Homes from broken families. Even if a proportion of such children have to be taken in care, every attempt is made to provide imaginative and alternative loving care and to encourage contact with the parents as much as possible. A lot still remains to be done and though co-operation exists between the Education, Medical, Housing and Police Departments and voluntary societies, the need exists for a Co-ordinating Committee of the se various services with some executive powers to function at two main levels:

(a) the top administrative level;

(b) the level of the workers directly concerned with the clients.

The intellectually and educationally subnormal young offender

The majority of young offenders we deal with, though appearing on the surface as tough and callous, are in reality still immature. They continue into adult life modes of feeling and patterns of behaviour that are characteristic of a childish state of development.

Here, however, I am mainly concerned with feebleminded young men, and in the case of offenders it is predominantly the high grade mental defective that we encounter rather than the severely subnormal. Mental subnormality by itself is not a cause of crime but crime may result when this mental condition is aggravated by some other factor such as emotional instability or an adverse environment. What is clear to us is that such persons seem to carry with them a feeling of inadequacy and frustration and it is not surprising that this consciousness of failure is of ten 
followed by misbehaviour. The usual pattern is apparent. He fails to keep pace at school, may become the laughing-stock of the class, starts truanting, easily falls into bad company, is easily caught and easily proved guilty.

The problem is not one that concerns only those who deal with juvenile offenders, but it is primarily a national problem in which the Education, Medical, Welfare and Employment services should play their part and co-ordinate their efforts to prevent overlapping. The Education Department with its Psychological Unit and Special Schools, the Disablement section of the Labour Office, the Psychiatric services of the Health Department and the Family Welfare Service of the Department of Social Services and voluntary societies all have a part to play. In my personal opinion comprehensive legislation to deal with and provide for the mentally retarded is required.

Economic, social and moral influences

The impact of social, economic and moral influences on our youth have, I believe, been taken up by other speakers and I do not intend therefore to dwell on this aspect, despite its great importance.

Is the minimum age of criminal re sponsibility adequate?

A major question that is often posed in connection with the treatment of young offenders is the adequacy of the minimum age of criminal responsibility. In Malta, children under nine years of age are presumed to be completely incapable of crime. Children between nine and fourteen years are criminally liable, if proved to have acted with "mischievous discretion".

In most countries of continental Europe, the age of criminal responsibility is rearely lower than thirteen years, in the majority it lies at fourteen, while in some countries as Belgium and Spain it is sixteen. Children under this age are dealt with as educational problems or by Welfare Agencies.

In Malta three main systems already exist which allow for a child between nine and under sixteen years of age to be dealt with as a "Welfare" rather than a "criminal" case. These are:

(a) A child under 16 years may be brought before the Juvenile Court under Section 6 of the Approved Schools Ordinance 
1921 as a "care and protection" case on application by the Director of Social Services for admission to St Philip Neri School, which is our Approved School, and to be there detained for two to five years but not later than his eighteenth birthday.

(b) A child under eighteen years may be admitted to a Home by the Court of Voluntary Jurisdiction of the Superior Courts if he is found in need of care and protection. This, in general, normally entails the admission of girls to the Good Shepherd Home, which is legally regarded as an Approved lnstitution. This Court acts like the "Family Court" existing in some countries.

(c) The practice arose in 1956/57, whereby in agreement with the Crown Advocate General, the Commissioner of Police started to refer cases of juveniles to the Head of the Welfare Division for investigation and advice. These are in the main persons who come to the attention of the Police for commission of an offence. Thorough social and psychological investigations are carried out and where there are indications of severe behaviour disorder, psychiatric examination and advice is sought. On the strength of the se investigations, the Welfare Division advices on the type of treatment required, and in agreement with the Commissioner of Police, undertakes to provide it or to arrange for it.

- These three systems clearly show that the machinery of dealing with young persons under sixteen as "care and protection cases" exists in Malta, but because the minimum age of criminal responsibility lies at nine years, the Police still have the power to bring a child over this age before the Court on a criminal charge.

The case in favour of raising the age of criminal responsibility seems to be overwhelming. In the first instance, it allows for the treatment of the offender rather than the offence. The offence is seen as just one symptom of a general maladjustment and not as the main and only is sue to be singled out for court action. Secondly, many children and juveniles brought before the court charged with an offence may be let off due to insufficient evidence or other technical reasons even though it becomes apparent to the presiding magistrate that the juvenile is in need of treatment. Finally, many children may be saved from being labelled as criminals and this is achieved not by letting them off but by giving them all the best possible treatment to re-educate them. 
It is suggested that the que stion of raising the age of criminal responsibility to sixteen years be considered. There is, of course, no objective criterion to justify it, but if the age is raised, children under this age can be dealt with by the Welfare Division that has the professional social workers and the institutions to deal with such problems. The Division would, of course, act on the decision taken in such cases by the Juvenile Court or the Court of Voluntary Jurisdiction following application to either of them by the Department of Social Services.

Methods of treatment available for young offenders

Primarily, the methods of treatment available for young offenders in Malta fall under two main categories:

(a) treatment that leaves the offender in the open community; and

(b) residential treatment, which necessitates the removal of the offender from his home for a shorter or a longer period.

Under the first category, the main methods used are absolute discharge, conditional discharge, Probation, Voluntary Supervision and fines.

The second group includes treatment at St Philip Neri School for boys, the Good Shepherd Home for Girls and imprisonment. methods used.

It is impossible, in such a short time to expand on the

My main suggestion here is that perhaps the increased use of Probation of offenders under the supervision of Probation Officers may reduce the amount of crime more than the mere application by the Courts of conditional discharge without the condition of supervision.

With regard to residential treatment, the establishment in Malta of quite a number of penal institutions available in large countries has been contemplated from time to time, such as Borstals, Detention Centres, Remand Homes and Probation Homes and Hostels. However, the smallness of the population makes the establishment of such institutions administratively and financially inexpedient. This has meant that the existing penal institutions 
have had to deal with a wide variety of offenders, thus increasing the problems each of them had to face, through the difficulty of proper classification.

Probation of Offenders system

It would be pertinent, I believe, to say something about the Probation of Offenders system, which is seen as one of the main instruments in the re-education and rehabilitation of young offenders. The Economic and Social Council of the United Nations regarded Probation as "one of the most important aspects in the development of a rational and social criminal policy" and they urged all governments to adopt or extend the system "as a major instrument of policy in the field of the prevention of crime and the treatment of offenders"(5). Similar emphasis was made in the Seminar I attended at the Crime Division of the Council of Europe, Strasbourg, in December, 1967.

In Malta the Probation of Offenders Act was passed in 1957 , but in view of the fact that the effectiveness and success of the whole system depends to a very large extent on the right selection and proper treatment of Probation Officers, the law did not come into operation under the 30th June, 1961, after the selected officers completed their training.

In brief the Act empowers the Court, on convicting a person of an offence, not punishable by hard labour or imprisonment for a term exceeding ten years, to make a probation order placing the offender under the supervision of a Probation Officer for a period of one to three years. This is done after the Court considers "the circumstances, including the nature of the offence and the character of the offender".

The probation order can stipulate any special requirements that seem desirable in view of the circumstances of the case. One requirement, that of residence in an institution for a period not exceeding twelve months, is specifically mentioned in the Act. The Court, however, may insert any other requirements that seem suitable, as for example, when the need is felt of enforcing a temporary break from adverse surroundings or undesirable associates.

The Court must explain in ordinary language the effect of the order and must make it clear to the offender that failure to comply with its terms will make him liable to be sentenced for the original offence. Thus the probationer knows from the 
beginning, as least intellectually if not always emotionally, that the possibility of punishment remains in the background and that on his behaviour depends whether he avoids it or not.

The consent of the probationer is required to a probation order, if he is over 14 years of age. This consent is rarely withheld, since refusal would probably lead to imprisonment. Nevertheless, such consent is not mere formality for it underlines the fact that he has to co-operate and play his part.

A probation order may be amended or discharged upon proper application, and ceases to have effect when the probationer is sentenced for his original offence. Failure to comply with the requirements of a probation order renders the probationer liable to be brought before the Court and fined for his breach. It may also deal with him for the offences in respect of which the order was made.

It is impossible in this talk to go into the intricacies of actual probation case-work but it may be said that probation relationships between officer and client go through five stages:

1. the examination stage, which includes the pre-sentence and post-sentence investigations;

2. the establishment of a treatment situation;

3. treatment proper;

4. termination of treatment;

5. post-probationary period.

Probation case-work depends for its success on two main factors:
(a) The proper selection of offenders for probation treatment by the Court

As was stated in the 1952 European Seminar on Probation: "Probation is not a mere 'second chance', or a standard form of leniency applicable to harmless offenders; it is a form of treatment with specific legal and therapeutic content, and care should be taken to exclude from it, not only those who are unlikely to respond favourably, or are likely to respond more favourably to an alternative form of treatment, but also those who 
do not need it" (6). This underlines the need and importance of proper pre-sentence investigations by Probation Officers for the Courts.

(b) The proper selection and Training of Probation Officers

"The essence of probation work is the influence for good of one man or woman upon another"(7). It can hardly be emphasized that it is not enough for the Probation Officer to have a sense of vocation but he must also possess the right personality and all this must be buttressed by the right type of training if he is to effect the desired changes in his probationer.

The Probation Order can be modified by the Court at any time. It can be adjusted as new problems arise and old problems are solved, or if the probation officer, as his understanding of the probationer deepens, finds that there are needs of which he had not previously been aware.

The results of probation in Malta show, that at least during the probationary period, about 90 per cent of the probationers terminated satisfactorily their term of probation.

Conclusions

To sum up, the following proposals are put forward:

1. In view of the fact that we know so little with any scientific precision about the causation of crime, the various countries should pool their resources and intensify their efforts on research work.

2. Considering that quite a proportion of youth delinquency has its roots in the home and in faulty early training, emphasis should be placed on preventive work, mainly by means of intensive family case-work and proper and up-to-date child-care services.

3. There is the need of fuller co-ordination between the various Government and voluntary bodies dealing with youth problems. Such co-ordination should occur at two main levels:

(a) the top administrative level;

(b) at the level of the workers directly concerned with the clients. 
4. Comprehensive legislation and co-operation between the various departments concerned are required to deal with the problem presented by intellectually subnormal youths.

5. The adequacy of the minimum age of criminal responsibility in Malta should be fully considered. If the age is raised to, say, sixteen, children and juveniles below this age showing delinquent behaviour can be dealt with by the Welfare Department.

6. The use of the Probation of Offenders system should be further extended for the re-education and rehabilitation of young offenders.

$\underline{\text { References }}$

1. Kretchsmer, E. Physique and Character, 1925.

2. Sheldon, W.A. Varieties of Delinquent Youth, 1949.

3. Gluech, S. and Gluech, E. After-Conduct of Discharged Offenders, 1945;

Gluech, S. and Gluech, E. Unravelling Juvenile Delinquency, 1950.

4. Bowlby, S. Maternal Care and Mental Health, 1951.

5. Foreword to the Report of the European Seminar on Probation, London, United Nations, October, 1952.

6. Ibid.

7. Report of the Departmental Committee on the Probation Service, Cmnd.1650, London, HMSO, 1962, paragraph 23.

Additional reading

Elkin, W.A: The English Penal System, 1957.

Jones, Dr. Howard. Crime and the Penal System, 1956. Jones, Dr. Howard. Crime in a Changing Society, 1965. 